\title{
Consumos e Usos dos Media (Infância) / Media Consumptions and Uses (Childhood)
}

https://doi.org/10.21814/uminho.ed.36.11

\section{Bula Bhadra}

University of Calcutta, India 



\section{Consumo e Uso dos Media (Infância)}

O consumo e os usos dos media, desde a introdução da televisão, são, e sempre foram, maiores que a vida. Consequentemente, agora é virtualmente impossível para as crianças imaginarem como seria crescer sem Internet, televisão, videogames e media social. A maioria das crianças de hoje cresce imersa nos media digitais e na digitalização, o que mudou a experiência da própria infância e das próprias crianças. Elas são expostas aos media em todas as formas, incluindo TV, computadores, tablets, smartphones e outros ecrãs.

Historicamente, desde que a televisão invadiu a paisagem norte-americana no final dos anos 1950 e o resto do mundo se juntou gradualmente, o seu impacto na vida diária das crianças tem sido objeto de intenso debate. A disponibilidade de uma gama cada vez maior de tecnologias de entretenimento - televisão por cabo e via satélite, juntamente com reprodutores de vídeo, DVD e DVR, permitiu maior escolha sobre o quê e quando as crianças assistiam; os videojogos tornaram-se baratos e facilmente disponíveis, e o consumidor adolescente tem hoje uma variedade quase estonteante de tecnologia de media de entretenimento para escolher.

Em parte, esta abundância de opções foi impulsionada pelo facto de essas tecnologias terem sido adotadas pela maioria das crianças em todo o mundo, embora com variações. Claramente, as crianças estão a crescer em ambientes cada vez mais saturados de media e tecnologia. A tecnologia digital oferece aos utilizadores a capacidade de usar mais media simultaneamente e o fenómeno da "multitarefa de media" tem aumentado. Um computador desktop ou portátil agora pode executar vários aplicativos simultaneamente, desde streaming de vídeo a programas de aplicativos residentes. A distribuição digital de media fez com que a media eletrónica se tornasse parte do quotidiano da maioria das crianças de formas até então inimagináveis.

O facto de as crianças terem abraçado mais rapidamente e incorporado com mais facilidade esses usos nas suas rotinas diárias aumentou as preocupações. O mundo digital agora constitui o mundo das crianças, onde outras pessoas tradicionalmente significativas são menos necessárias ou às vezes nem mesmo necessárias. Entre as décadas de 1960 e 1980, por exem- 
plo, o uso de media pelas crianças resultou principalmente em mais tempo gasto em frente à televisão. Entretanto, hoje em dia, as formas tradicionais de assistir TV estão em declínio entre classes, géneros e etnias em todo o mundo. Sem dúvida, as crianças simplesmente têm mais opções de media hoje - tanto em termos dos usos da tecnologia de media quanto do conteúdo disponível - e essas opções são parte integrante das experiências por elas vividas. Com todas estas opções, não é uma surpresa que as crianças tenham, também, mais probabilidades do que no passado de executar multitarefas de media e de maior consumo médio.

No entanto, em todo o mundo, este tipo de desenvolvimentos é evidentemente realizado de forma desigual, devido à prevalência de uma divisão digital entre quem tem e quem não tem. Ainda assim, a noção de que os media participativos e colaborativos - como software de mistura de música, câmaras digitais e software de edição - estão disponíveis para a maioria não é enganosa, mesmo num mundo que é estratificado por desigualdades económicas, sociais e políticas.

Deste modo, por um lado, muitos pais temem que ficar sentados em frente a um computador ou televisão por longos períodos de tempo possa levar a ganhos de peso, insónias ou, ainda, que mensagens instantâneas intermináveis possam interferir na capacidade dos filhos estabelecerem relacionamentos face a face. As incertezas sobre o modo como as crianças consomem os media contemporâneos também estão repletas de medos antigos sobre como os velhos e novos media trazem imagens e histórias violentas para a vida das crianças e adolescentes. Há um profundo sentimento de insegurança e cautela entre pais e educadores, muitos dos quais se sentem ultrapassados e mal equipados para responder à vida digital. No entanto, eles simultaneamente sentem uma enorme pressão para lidar com a mudança na cultura dos media que parece fazer parte do futuro dos seus filhos.

O que é verdade hoje é que as crianças estão a crescer em ambientes de comunicação cada vez mais complexos. A Internet permite a comunicação um-para-um (como o telefone e a interação face a face) e a comunicação um-para-muitos (o que também vale para as transmissões mais antigas ou meios de comunicação de massa, como a televisão e os filmes). Também permite formas de comunicação muitos-para-muitos (como em jogos online multiplayer massivos), algo que é uma caraterística única das redes digitais. Isto permite que os media de hoje se expandam em novas direções e lugares, encontrando novos caminhos na vida das crianças e contribuindo para a reconfiguração de oportunidades e riscos nas suas vidas em relação 
a atividades sociais, culturais, educacionais, cívicas, de saúde e de lazer importantes.

Em sociedades cada vez mais globalizadas e fragmentadas, pode parecer que as redes sociais das pessoas estão em declínio, que as pessoas estão a viver vidas mais solitárias e desconectadas. Mas o individualismo e a hipersociabilidade em rede chamam a atenção para as muitas maneiras pelas quais as crianças pequenas agora podem expressar-se, interagir umas com as outras e participar em públicos em rede através de diferentes recursos de informação. A mensagem, no entanto, é que, embora essa participação muitas vezes possa parecer imensamente promissora, os ambientes mediados digitalmente são entrelaçados com tramas, formas textuais, práticas de marketing e mercadorias afetivas de empresas comerciais. Posteriormente, o que resulta é um paradoxo de participação. Enquanto as culturas dos media contemporâneos podem envolver a imaginação coletiva dos jovens e [permitir] novos "géneros de participação", muitos adultos expressam preocupações sobre o papel da comercialização excessiva e consumismos indulgentes.

Atualmente, as novas tecnologias de media digital permitem que as crianças misturem as suas próprias músicas, montem as suas próprias histórias e editem as suas próprias imagens e vídeos, oferecendo, assim, enormes oportunidades para que se assumam como agentes.

A participação e os usos da media agora são caracterizados pela personalização (as crianças criam identidades específicas através das suas páginas do Facebook), hipersociabilidade (uma capacidade constante e até mesmo expectativa de estar "disponível"), networking (as crianças podem alcançar e ser alcançadas pelos media em várias plataformas, horários e lugares) e omnipresença (há muito mais media eletrónica e digital do que nunca).

N.B. [O texto acima representa mais o Norte Global e o Sul Global industrializado urbano dos tempos atuais.]

\section{Media Consumption and Uses}

Media consumption and uses, since the introduction of television are, and always have been larger than life. Consequently, it is now virtually impossible for children to imagine what it would be like to grow up without the Internet, television, video games, and social media. The majority of children today are growing up immersed in digital media and digitization which has changed the experience of childhood itself and children themselves. 
They are exposed to media in all forms, including TV, computers, tablets, smart phones, and other screens. Historically, since television roared onto the North American landscape by the late 1950s and the rest of the world joined gradually, its impact on children's daily life has been the subject of intense discourse. The availability of an increasing array of entertainment technologies - cable and satellite television along with video, DVD, and DVR players allow increased choice in what children will watch and when they will watch; video game players have become inexpensive and easily available; home computers today are as powerful as some mainframes of the early 1980s and by all accounts, iPods are, globally speaking, de rigueur for wealthy teenagers. The adolescent child consumer today has an almost dizzying medley of entertainment media technology to choose from. In part, this plethora of choice has been driven by the fact that these technologies have been embraced by majority of children globally, though with variation. Clearly, children are growing up in increasingly media- and technology-saturated environments. Digital technology offers users the capability to use more media simultaneously and the phenomenon of "media multitasking" has risen. A desktop or notebook computer can now run multiple applications simultaneously, everything from streaming video to resident application programs. The digital delivery of media has meant that electronic media have become part of the fabric of the majority of children's daily lives in heretofore unimagined ways. The fact that children have embraced more rapidly and incorporated more effortlessly these uses into their daily routines has heightened concerns. The digital world now constitutes the children's world where traditional significant and generalized others either are less required or sometimes not required at all. Between the 1960s and 1980 s, for example, children's media use mostly amounted to more time spent in front of the television. Today, however, amongst classes, genders, and ethnicities across the globe, traditional forms of TV viewing are on the decline. No doubt, children simply have more media options today - both in terms of the media technology uses and the content available - and these options are an integral part of the lived experiences of children. With all these media options available, it would not be a surprise that children are also much more likely than in the past to be media multitaskers, capable of packing more media into any given hour of consumption.

However, around the world these kinds of developments are of course unevenly realized due to the prevalence of a digital divide between haves and have-nots. Nonetheless, the notion that participatory, collaborative media - like music mixing software, digital cameras, and editing software - is available to the majority is not misleading even in a world that is stratified by 
economic, social, and political inequities. Accordingly, many parents fear that sitting in front of a computer or television for extended periods of time can lead to weight gain, or sleep deprivation, or that endless instant messaging can interfere with children's ability to form face-to-face relationships. Uncertainties about how children consume contemporary media are also layered with longstanding fears about how old and new media bring violent images and stories into adolescent's lives. There is a deep sense of insecurity and wariness among parents and educators, many of whom feel behind the curve and ill-equipped to respond to digital life. Yet, they simultaneously feel a tremendous pressure to address the changing media culture that seems likely to be a part of their children's futures. What is true today is that children are growing up in an increasingly complex communication environment. The Internet allows for both one-to-one communication (like the telephone and face-to-face interaction) and one-to-many communication (which is also true of older broadcast or mass media, like the television and movies). It also allows for many-to-many forms of communication (as in massive multiplayer online games), something that is a unique characteristic of digital networks. This allows today's media to expand in new directions and places, finding new routes into children's lives and contributes to the reconfiguration of opportunities and risks in their lives in relation to social, cultural, educational, civic, health, and important leisure activities. In increasingly globalizing, fragmented societies, it can appear that people's social networks are in decline, that people are living more lonely, disconnected lives. But networked individualism and hypersociality draw attention to the many ways young children can now express themselves, interact with each other, and participate in networked publics through information resources. The message, however, is that, while such participation can often seem immensely promising, digitally mediated environments are thread through with the plots, textual forms, marketing practices, and affective commodities of commercial corporations. Subsequently, what results is a participation paradox. While contemporary media cultures may engage young people's collective imagination and [afford] new "genres of participation", familiar worries about the role of excessive commercialization and indulgent consumerisms continue to resound.

Nowadays, new digital media technologies allow young children to mix their own music, mount their own stories, and edit their own images and videos, thus offering tremendous opportunities for children to take a stand and gain agency. Media participation and uses are now characterized by personalization (kids create specific identities through their Facebook pages), hypersociality (a constant ability and even expectation to be "available"), 
networking (young children can reach out to, and be reached by, media across various platforms, times, and places), and ubiquity (there is just much more electronic and digital media than ever before).

N.B. [Children's Media Consumption and Uses is uneven according to class, gender, language, country, region, (dis)ability etc. In a way, the above write up is more representative of Global North than Global South of the present day.]

\section{Referências / References}

Buckingham, D. (2006). Is There a Digital Generation? In David Buckingham and Rebekah Willett (Eds.), Digital Generations: Children, Young People, and New Media (pp. 1-13). London: Lawrence Erlbaum Associates.

Castells, M. (2001). The Internet Galaxy. Oxford: Oxford University Press.

Livingstone, S. (2009). Children and the Internet: Great Expectations, Challenging Realities. Cambridge: Polity Press.

Turkle, S. (2011). Alone Together: Why We Expect More from Technology and Less from Each Other. New York: Basic Books. 